\title{
Moringa oleifera leaf meal as an environmental friendly protein source for ruminants: Biomethane and carbon dioxide production, and fermentation characteristics
}

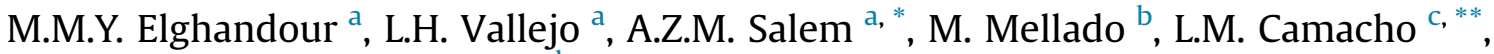 \\ M. Cipriano ${ }^{c}$, O.A. Olafadehan ${ }^{\mathrm{d}}$, J. Olivares ${ }^{\mathrm{c}}$, S. Rojas ${ }^{\mathrm{c}}$ \\ a Facultad de Medicina Veterinaria y Zootecnia, Universidad Autónoma del Estado de México, Estado de México, Mexico \\ ${ }^{\mathrm{b}}$ Department of Animal Nutrition, Autonomous Agrarian University Antonio Narro, Saltillo, Mexico \\ ${ }^{\mathrm{c}}$ Facultad de Medicina Veterinaria y Zootecnia, Universidad Autónoma de Guerrero, Cd. Altamirano, Guerrero, Mexico \\ ${ }^{\mathrm{d}}$ Department of Animal Science, University of Abuja, Abuja, Nigeria
}

\section{A R T I C L E I N F O}

\section{Article history:}

Received 3 February 2017

Received in revised form 19 July 2017

Accepted 19 July 2017

Available online 22 July 2017

\section{Keywords:}

Greenhouse gases

Goats

M. oleifera leaf meal

Protein feeds

Steers

\begin{abstract}
A B S T R A C T
Ruminal fermentation produces methane $\left(\mathrm{CH}_{4}\right)$ and carbon dioxide $\left(\mathrm{CO}_{2}\right)$ which contribute to global warming. Therefore, several enteric $\mathrm{CH}_{4}$ and $\mathrm{CO}_{2}$ mitigation strategies have been explored recently. In this trial the effect of replacing soybean meal, as the sole protein source in a control total mixed ration (TMR) with Moringa oleifera leaf meal (MLM) at different levels, on ruminal fermentation characteristics were studied. M. oleifera leaf meal replaced (g/100 g DM): 0 (TMR0, control), 10 (TMR10), 20 (TMR20), 30 (TMR30), 40 (TMR40), 50 (TMR50), 60 (TMR60), 70 (TMR70), 80 (TMR80), 90 (TMR90), and 100 (TMR100) of soybean meal in the rations. Rations were incubated for $48 \mathrm{~h}$ using rumen inoculums from goats and steers. Some interactions between inoculum $\times$ TMR were observed $(P<0.05)$ for gas production (GP) parameters, $\mathrm{CH}_{4}$ production, and fermentation profile. Moreover, most parameters determined responded differently between animal species. Rations containing MLM decreased the asymptotic GP $(P<0.01)$, while they increased $(P<0.01)$ the rate of GP and lag of GP with both inoculums. Decreased $(P<0.05) \mathrm{CH}_{4}$ production and increased $\mathrm{CO}_{2}$ production $(P<0.05)$ were observed when MLM replaced soybean meal. Diets containing MLM decreased $(P<0.05)$ ruminal ammonia-N and total protozoal number, while increasing $(P<0.05)$ total bacterial number with both goat and steer inoculums. Replacing soybean meal with MLM increased $(P<0.05)$ fermentation $\mathrm{pH}$, but decreased $(P<0.05)$ organic matter degradability (OMD) with goat inoculum. Conversely, a declined $(P<0.05)$ in SCFA concentrations, and enhanced $(P<0.05)$ OMD and DM degradability compared with the control diet was observed with diets containing MLM. It is concluded that replacing soybean meal in goat and steer diets negatively affected the nutritive value of diets but decreased $\mathrm{CH}_{4}$ production. From an environmental standpoint, the replacement of soybean meal with MLM is a potential sustainable strategy to reduce $\mathrm{CH}_{4}$ production from goats and steers, and thus mitigate greenhouse gas emissions. Goat inoculum was more efficient in reducing $\mathrm{CH}_{4}$ production than that of steers.
\end{abstract}

๑) 2017 Elsevier Ltd. All rights reserved.

\section{Introduction}

There is a growing global concern for the environmental impact of greenhouse gases (methane, carbon dioxide and nitrous oxide)

\footnotetext{
* Corresponding author.

** Corresponding author.

E-mail addresses: asalem70@yahoo.com (A.Z.M. Salem), caamacho@hotmail. com (L.M. Camacho).
}

emissions by ruminant production systems. Estimates of global production of enteric methane from ruminants are about $80,000 \mathrm{Gg}$ (Ku-Vera et al., 2013). Increasing future feedstuffs demand for livestock and food-feed-fuel competition have environmental and social impacts (Gopalakrishnan et al., 2016; Makkar, 2016). The growing demand of livestock products is accompanied by social, economic and environmental challenges (Makkar, 2016). During ruminal fermentation of feeds, large amounts of greenhouse gases are produced making livestock one of most important greenhouse gases producers. Food and Agriculture Organization (FAO, 2006) 
reported that the livestock sector accounts for about $18 \%$ of methane $\left(\mathrm{CH}_{4}\right)$ and $9 \%$ of carbon dioxide $\left(\mathrm{CO}_{2}\right)$ productions. Enteric $\mathrm{CH}_{4}$, a product of ruminal anaerobic fermentation produced by methanogenic archaea during disposal of metabolic $\mathrm{H}_{2}$ produced by their metabolic activity, contributes $30-40 \%$ of the total $\mathrm{CH}_{4}$ production from agricultural sources (Moss et al., 2000). Many attempts have been made to mitigate $\mathrm{CH}_{4}$ emission from ruminants including the inclusion of yeast (Elghandour et al., 2017), organic acids salt (Elghandour et al., 2016), exogenous enzymes (Kholif et al., 2017a), and essential oils (Hernandez et al., 2017), with promising results.

Animal producers face a series of problems; one of them is the availability and high price of concentrates, in particular protein sources, which compel nutritionists to seek for less-expensive alternative protein feeds (Kholif et al., 2015). Tree leaves have been used to ameliorate this problem. Moringa oleifera Lam (syns. Moringa pterygosperm family Moringaceae) is a fodder tree growing almost worldwide and yields a high amount of biomass ranging from 43 to 115 tons per hectare (Safwat et al., 2014), with a high protein content. Kholif et al. (2015) reported the chemical composition as a protein feed containing (/kg DM) 241-277 g crude protein (CP), with about 47\% of bypass protein (Becker, 1995), adequate amino acid profile (Sánchez-Machado et al., 2010) and polyphenolics contents as antioxidant (Nouman et al., 2016). $M$. oleifera is a cheaper protein ingredient than most traditional protein feeds such as sesame and soybean meal (Kholif et al., 2015). However, like other fodder trees, M. oleifera contains secondary metabolites (Kholif et al., 2015). Plants having bioactive products such as essential oils, saponins, and condensed tannins (Guglielmelli et al., 2011; Calabrò et al., 2011) with antimicrobial properties may be exploited in ruminant production to reduce $\mathrm{CH}_{4}$ emissions and improve fermentation efficiency. Little information about MLM as a protein source for ruminants is available; however, recent experiments that included MLM as a protein feed are gaining increasing interests, with promising results such as enhanced feed utilization and milk production from goats (Kholif et al., 2015). Unfortunately, they did not study the effect of replacing soybean meal with MLM as a protein source on greenhouse gases production using inoculums from two different livestock species. Therefore, the present study aimed to evaluate the effects of replacing soybean meal at different levels with MLM in diets for ruminants, as a "clean" feed for the environment, on the sustainable mitigation of $\mathrm{CH}_{4}$ and $\mathrm{CO}_{2}$ production, ruminal fermentation profile, and $\mathrm{CH}_{4}$-producing protozoa and bacteria using rumen inoculums from goats and steers.

\section{Materials and methods}

\subsection{Substrate and treatments}

M. oleifera leaf meal was prepared as previously described by Kholif et al. (2015). Briefly, M. oleifera leaves and small twigs were harvested at $40 \mathrm{~d}$ of age. M. oleifera was air-dried at $60^{\circ} \mathrm{C}$ for $48 \mathrm{~h}$, and then kept for further use. Total tannin concentration of M. oleifera leaves was determined according to Makkar (2003), and total phenolic content was determined chromatographically as described by Meier et al. (1988). M. oleifera contained $22 \mathrm{~g} / \mathrm{kg}$ DM total tannins and $48 \mathrm{~g} / \mathrm{kg}$ DM total phenolic contents. A total mixed ration (TMR) was prepared, as a substrate containing (/kg DM) $400 \mathrm{~g}$ alfalfa hay (Medicago sativa), $250 \mathrm{~g}$ crushed yellow corn, $250 \mathrm{~g}$ soybean meal, and $100 \mathrm{~g}$ wheat bran, and considered as a control. Rations were balanced for minerals and vitamins contents. In the basal TMR, dried MLM replaced soybean meal at (/100 g DM): $0 \mathrm{~g}$ (TMR0, control), $10 \mathrm{~g}$ (TMR10), $20 \mathrm{~g}$ (TMR20), $30 \mathrm{~g}$ (TMR30), $40 \mathrm{~g}$ (TMR40), $50 \mathrm{~g}$ (TMR50), $60 \mathrm{~g}$ (TMR60), $70 \mathrm{~g}$ (TMR70), $80 \mathrm{~g}$ (TMR80),
$90 \mathrm{~g}$ (TMR90), and $100 \mathrm{~g}$ (TMR100). The chemical composition of ingredients and TMRs used is shown in Table 1.

\subsection{In vitro fermentation and biogases production}

Rumen inoculums were collected from two ruminally cannulated Holstein steers $(450 \pm 20 \mathrm{~kg} \mathrm{LW})$, and two cannulated Creole goats $(50 \pm 2 \mathrm{~kg} \mathrm{LW})$, housed in individual pens and fed ad libitum on a diet consisting of oat hay and concentrate (PURINA ${ }^{\circledR}$, Toluca, Mexico) at 60:40 ratio. Animals were fed twice daily at 08:00 and 16:00 $\mathrm{h}$, and managed under the conditions stipulated in the Official Mexican Standard of technical specifications for the production, care and use of laboratory animals (NOM-062-ZOO-1999). Rumen contents were placed in a plastic thermo preheated at $39^{\circ} \mathrm{C}$. They were flushed with $\mathrm{CO}_{2}$, mixed and strained through four layers of cheesecloth into a flask with $\mathrm{O}_{2}$-free headspace, and maintained at a constant temperature of $39{ }^{\circ} \mathrm{C}$ and continuous $\mathrm{CO}_{2}$ flow.

Before the incubation process, incubation media was prepared according to Goering and Van Soest (1970), mixed in a volumetric flask using a platen and magnetic stirrer at $39^{\circ} \mathrm{C}$ to maintain the temperature and homogenize the solution. Then, the ruminal inoculum and the reducing solution were added at 1:4 vol/vol, respectively.

Samples $(0.5 \mathrm{~g})$ of the substrate were weighed into $120 \mathrm{~mL}$ serum bottles, and $50 \mathrm{~mL}$ of previously prepared rumen liquor and the buffer solution were added. Bottles were maintained under a constant $\mathrm{CO}_{2}$ flow for $30 \mathrm{~s}$, capped with neoprene plugs and sealed with aluminum rings. The vials were placed in an incubator $\left(\right.$ Riossa $^{\circledR}, \mathrm{F}-51 \mathrm{D}$, Mexico State, Mexico) at $39^{\circ} \mathrm{C}$ for $48 \mathrm{~h}$. Moreover, three bottles as blanks (rumen fluid only) were incubated for $48 \mathrm{~h}$. Three incubation runs were performed in three weeks.

The total gas production (GP) readings were taken after $2,4,6,8$, $10,12,24$ and $48 \mathrm{~h}$ of incubation. A water displacement apparatus was used according to Fedorak and Hrudey (1983). The vials were punctured with a 16-gauge needle placed at the end of the hose. The GP $(\mathrm{mL})$ was measured by the displacement of water in the burette.

After $48 \mathrm{~h}$ incubation, $5 \mathrm{~mL}$ of gas was taken and stored in the vials containing saturated saline solution prepared with $400 \mathrm{~g}$ of $\mathrm{NaCl}$ in $1 \mathrm{~L}$ of distilled water, and the $\mathrm{pH}$ was adjusted at 2 , and $5 \mathrm{~mL}$ of $20 \%$ methyl orange was added as indicator for $\mathrm{CH}_{4}$ and $\mathrm{CO}_{2}$ concentrations determination. The saturated saline solution was previously prepared and stored in $60 \mathrm{~mL}$ serological vials, leaving no space; and neoprene plugs were placed and sealed with aluminum rings, and stored away from light. For the $\mathrm{CH}_{4}$ and $\mathrm{CO}_{2}$ determination from vials, a $10 \mu \mathrm{L}$ sample of the gas phase was taken and injected into a Perkin-Elmer, Claurus 500 gas chromatograph (Mexico City, Mexico) with a flame ionization detection, and helium as the carrier gas. A thermal conductivity detector was used; the oven, column and FID (A flame ionization detector) temperatures were $80^{\circ} \mathrm{C}, 170{ }^{\circ} \mathrm{C}$ and $130{ }^{\circ} \mathrm{C}$, respectively. Retention times were $0.73 \mathrm{~min}$ and $1.05 \mathrm{~min}$ for $\mathrm{CH}_{4}$ and $\mathrm{CO}_{2}$, respectively.

At the end of $48 \mathrm{~h}$ incubation period, the fermentation process was stopped by swirling the bottles in ice for $5 \mathrm{~min}$. The bottles were subsequently uncapped and the $\mathrm{pH}$ was measured using a $\mathrm{pH}$ meter (Thermo Scientific, Orion Star ${ }^{\mathrm{TM}}$ A121, Beverly, MA, USA). The contents of the bottles were filtered in Ankom ${ }^{\circledR}$ Technologies F57 bags (at constant weight). The bottles were rinsed with a hot water 3 times to ensure recovery of all the fermentation residues. The bags were placed in a forced-air oven at $55{ }^{\circ} \mathrm{C}$ for $48 \mathrm{~h}$. Dry matter degradation was calculated by considering the initial weight of the substrate and the weight of the residue.

After $\mathrm{pH}$ measurement and filtration, $4 \mathrm{~mL}$ of the medium were obtained with a syringe and mixed with $1 \mathrm{~mL}$ of $25 \%$ metaphosphoric acid, shaken slightly and placed under freezing for the 
Table 1

Chemical composition ${ }^{\mathrm{a}}$ of ingredients and total mixed rations (TMR) with different levels of Moringa oleifera replacing soybean meal as a protein source.

\begin{tabular}{|c|c|c|c|c|c|c|c|c|c|c|}
\hline & $\mathrm{DM}$ ( $\mathrm{g} / \mathrm{kg}$ wet material) & $\mathrm{OM}$ & $\mathrm{CP}$ & $\mathrm{EE}$ & NSC & NDF & ADF & ADL & Cellulose & Hemicellulose \\
\hline \multicolumn{11}{|l|}{ Ingredients } \\
\hline Alfalfa hay & 902.0 & 885.8 & 189.2 & 25.3 & 218.9 & 452.4 & 330.1 & 82.1 & 248.0 & 122.3 \\
\hline M. oleifera hay & 868.2 & 891.0 & 281.1 & 40.9 & 224.4 & 344.6 & 301.0 & 77.6 & 223.4 & 43.6 \\
\hline Crushed yellow corn & 866.0 & 890.3 & 90.8 & 45.2 & 540.0 & 214.3 & 88.8 & 10.4 & 78.4 & 125.5 \\
\hline Soybean meal & 889.0 & 927.9 & 408.1 & 21.4 & 355.7 & 142.7 & 96.3 & 8.8 & 87.5 & 46.4 \\
\hline Wheat bran & 871.4 & 852.2 & 129.7 & 56.2 & 204.4 & 461.9 & 130.6 & 38.0 & 92.6 & 331.3 \\
\hline \multicolumn{11}{|l|}{ Total mixed rations ${ }^{\mathrm{b}}$} \\
\hline TMRO & 886.7 & 894.1 & 213.4 & 32.4 & 331.9 & 316.4 & 191.4 & 41.4 & 149.9 & 125.0 \\
\hline TMR10 & 886.2 & 893.2 & 210.2 & 32.9 & 328.6 & 321.4 & 196.5 & 43.2 & 153.3 & 125.0 \\
\hline TMR20 & 885.7 & 892.2 & 207.0 & 33.4 & 325.4 & 326.5 & 201.6 & 44.9 & 156.7 & 124.9 \\
\hline TMR30 & 885.1 & 891.3 & 203.9 & 33.9 & 322.1 & 331.5 & 206.7 & 46.6 & 160.1 & 124.8 \\
\hline TMR40 & 884.6 & 890.4 & 200.7 & 34.3 & 318.8 & 336.6 & 211.8 & 48.3 & 163.5 & 124.7 \\
\hline TMR50 & 884.1 & 889.5 & 197.5 & 34.8 & 315.5 & 341.6 & 217.0 & 50.0 & 166.9 & 124.7 \\
\hline TMR60 & 883.6 & 888.6 & 194.3 & 35.3 & 312.2 & 346.7 & 222.1 & 51.8 & 170.3 & 124.6 \\
\hline TMR70 & 883.1 & 887.6 & 191.2 & 35.8 & 308.9 & 351.7 & 227.2 & 53.5 & 173.7 & 124.5 \\
\hline TMR80 & 882.5 & 886.7 & 188.0 & 36.3 & 305.7 & 356.8 & 232.3 & 55.2 & 177.1 & 124.5 \\
\hline TMR90 & 882.0 & 885.8 & 184.8 & 36.8 & 302.4 & 361.8 & 237.4 & 56.9 & 180.5 & 124.4 \\
\hline TMR100 & 881.5 & 884.9 & 181.6 & 37.3 & 299.1 & 366.9 & 242.6 & 58.6 & 183.9 & 124.3 \\
\hline
\end{tabular}

a ADF, acid detergent fiber; CP, crude protein; DM, dry matter; EE, ether extract; NDF, neutral detergent fiber; NSC, non-structural carbohydrates; OM, organic matter.

b Moringa oleifera replaced 0 (TMR0), 10 (TMR10), 20 (TMR20), 30 (TMR30), 40 (TMR40), 50 (TMR50), 60 (TMR60), 70 (TMR70), 80 (TMR80), 90 (TMR90), and 100 (TMR100) $\mathrm{g} / 100 \mathrm{~g}$ of soybean meal.

analysis of ammonia- $\mathrm{N}\left(\mathrm{NH}_{3}-\mathrm{N}\right)$ concentration. Other $4 \mathrm{~mL}$ of the medium were mixed with $1 \mathrm{~mL} 10 \%$ formaldehyde, shaken slightly and placed in refrigeration for bacterial and protozoal counting.

\subsection{Total bacteria and protozoa counting}

The population of total bacteria was determined after $48 \mathrm{~h}$ incubation using a count chamber bacterium Petroff-Hausser (Hausser Scientific ${ }^{\mathbb{R}}, 3900$, Horsham, PA) and a phase contrast microscope (Olympus ${ }^{\circledR}$, BX51, Mexico City, Mexico) at a magnification of $100 \times$. Exactly, $0.5 \mathrm{~mL}$ of the $10 \%$ formaldehyde fixed medium sample was taken and diluted in $4.5 \mathrm{~mL}$ of distilled water. The bacteria concentration per $\mathrm{mL}$ was determined as the average of bacteria observed in each grid, multiplied by the dilution factor and the chamber factor $\left(2 \times 10^{7}\right)$, according to the following formula:

Bacterial number $/ \mathrm{mL}=\mu \times \mathrm{FD} 1 \times \mathrm{FD} 2 \times 2^{7}$.

where: $\mu$ is the average of bacteria in each grid per treatment, FD1 is the first dilution factor (1.25), and FD2 is the second dilution factor (10).

For the protozoal number determination, $1 \mathrm{~mL}$ of the $10 \%$ formaldehyde fixed sample was obtained and diluted in $1 \mathrm{~mL}$ of distilled water; then $0.5 \mathrm{~mL}$ of the mixture was taken with a Pasteur pipette (BRAND, 7712, Wertheim, Germany) which were deposited in a Neubauer chamber (BRAND, 7178-10, Wertheim, Germany) and subsequently observed under contrast-phase microscopy (Carl Zeiss $^{\circledR}$, Axiostar, Mexico City, Mexico) at $400 \times$ magnifications. The count of protozoa was made in eight quadrants ( 4 of each grid), taking as viable protozoans those that maintained their morphological integrity. Protozoa concentration per $\mathrm{mL}$ of culture medium was estimated as the average protozoa observed in each grid, multiplied by the dilution factor and the chamber factor $\left(1 \times 10^{4}\right)$, according to the following formula:

Protozoal number $=\mu \times \mathrm{FD} 1 \times \mathrm{FD} 2 \times 10^{4}$

where: $=\mu$ is the average of protozoa in each grid per treatment, FD1 is the first dilution factor (5), and FD2 is the second dilution factor (3).

\subsection{Chemical analyses}

Samples of diets were analyzed for DM, ash, N and EE according to AOAC (1997), while the neutral detergent fiber (NDF) (Van Soest et al., 1991), and acid detergent fiber (ADF) and lignin (AOAC, 1997; \#973.18) analyses were carried out using an ANKOM $^{200}$ Fiber Analyzer Unit (ANKOM Technology Corp., Macedon, NY, USA) with the use of an alpha amylase and sodium sulfite.

The concentration of ruminal $\mathrm{NH}_{3}-\mathrm{N}$ was determined according to Broderick and Kang (1980) methods. Samples of the incubation medium were centrifuged at $3000 \times \mathrm{g}$ for $10 \mathrm{~min}$, and $20 \mu \mathrm{L}$ of the supernatant was mixed with $1 \mathrm{~mL}$ of phenol and $1 \mathrm{~mL}$ of hypochlorite, and the mixture was incubated at $39{ }^{\circ} \mathrm{C}$ for $30 \mathrm{~min}$, after they were diluted with $5 \mathrm{~mL}$ of distilled water. Samples were read on a visible ultraviolet light spectrophotometer (Varian, model Cary $1 \mathrm{E}$, California, USA) at $630 \mathrm{~nm}$. The resulting $\mathrm{g} / \mathrm{L}$ concentration was divided by 0.8 which was the $25 \%$ metaphosphoric acid dilution factor.

\subsection{Calculations and statistical analyses}

For estimation of GP kinetic, recorded gas volumes (mL/g DM) were fitted using the NLIN procedure of SAS (2002) according to the model of France et al. (2000):

$\mathrm{y}=\mathrm{b} \times\left[1-\mathrm{e}^{-\mathrm{c}(\mathrm{t}-\mathrm{L})}\right]$

where $y$ is the volume of GP at time $t(h)$; $b$ is the asymptotic GP $(\mathrm{mL} / \mathrm{g} \mathrm{DM}) ; \mathrm{c}$ is the fractional rate of fermentation $(/ \mathrm{h})$, and $\mathrm{L}(\mathrm{h})$ is the discrete lag time prior to the time any gas was released.

Metabolizable energy (ME, MJ/kg DM) and in vitro organic matter digestibility (OMD, $\mathrm{g} / \mathrm{kg} \mathrm{DM}$ ) were estimated according to Menke et al. (1979) as:

$\mathrm{ME}=2.20+0.136 \mathrm{GP}(\mathrm{mL} / 0.5 \mathrm{~g} \mathrm{DM})+0.057 \mathrm{CP}(\mathrm{g} / \mathrm{kg} \mathrm{DM})$

$$
\begin{aligned}
\mathrm{OMD}= & 148.8+8.89 \mathrm{GP}+4.5 \mathrm{CP}(\mathrm{g} / \mathrm{kg} \mathrm{DM}) \\
& +0.651 \mathrm{ash}(\mathrm{g} / \mathrm{kg} \mathrm{DM})
\end{aligned}
$$

where GP is net GP in $\mathrm{mL}$ from $200 \mathrm{mg}$ of dry sample after $24 \mathrm{~h}$ of 
Table 2

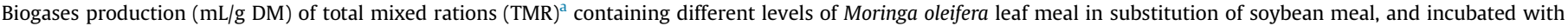
rumen liquors obtained from goats or steers.

\begin{tabular}{|c|c|c|c|c|c|c|c|c|c|c|c|}
\hline \multirow[t]{2}{*}{ Inoculum } & \multirow[t]{2}{*}{ TMR } & \multicolumn{4}{|c|}{ Gas production parameters ${ }^{b}$} & \multicolumn{3}{|c|}{$\mathrm{CO}_{2}$ production at $48 \mathrm{~h}$ of incubation } & \multicolumn{3}{|c|}{$\mathrm{CH}_{4}$ production at $48 \mathrm{~h}$ of incubation } \\
\hline & & $b$ & $c$ & Lag & $\begin{array}{l}\mathrm{mL} \text { gas } / \mathrm{g} \\
\text { degraded } \\
\mathrm{DM}\end{array}$ & $\begin{array}{l}\mathrm{mL} \\
\mathrm{CO}_{2} / \mathrm{g} \\
\text { incubated } \mathrm{DM}\end{array}$ & $\begin{array}{l}\text { Proportional } \mathrm{CO}_{2} \\
\text { production }\end{array}$ & $\begin{array}{l}\mathrm{mL} \\
\mathrm{CO}_{2} / \mathrm{g} \\
\text { degraded } \\
\mathrm{DM}\end{array}$ & $\begin{array}{l}\mathrm{mL} \mathrm{CH}_{4} / \mathrm{g} \\
\text { incubated } \\
\mathrm{DM}\end{array}$ & $\begin{array}{l}\text { Proportional } \\
\mathrm{CH}_{4} \\
\text { production }\end{array}$ & $\begin{array}{l}\mathrm{mL} \mathrm{CH}_{4} / \mathrm{g} \\
\text { degraded DM }\end{array}$ \\
\hline \multirow[t]{11}{*}{ Goat } & TMRO & 288 & 0.091 & 1.39 & 369 & 200 & 70.4 & 315 & 61.4 & 21.6 & 53.7 \\
\hline & TMR10 & 291 & 0.096 & 1.91 & 376 & 235 & 81.7 & 321 & 42.1 & 14.6 & 55.1 \\
\hline & TMR20 & 257 & 0.108 & 2.62 & 336 & 208 & 81.5 & 282 & 41.5 & 16.3 & 54.4 \\
\hline & TMR30 & 235 & 0.106 & 2.77 & 309 & 201 & 86.1 & 256 & 30.9 & 13.2 & 52.7 \\
\hline & TMR40 & 267 & 0.109 & 2.53 & 357 & 212 & 79.7 & 291 & 49.3 & 18.5 & 66.3 \\
\hline & TMR50 & 280 & 0.116 & 2.56 & 381 & 223 & 80.0 & 311 & 51 & 18.3 & 69.5 \\
\hline & TMR60 & 262 & 0.106 & 2.46 & 343 & 202 & 77.5 & 278 & 49.7 & 19.1 & 65.5 \\
\hline & TMR70 & 268 & 0.118 & 2.48 & 365 & 214 & 80.1 & 299 & 48.3 & 18.1 & 66 \\
\hline & TMR80 & 269 & 0.124 & 2.54 & 356 & 216 & 80.4 & 291 & 49.3 & 18.3 & 65.2 \\
\hline & TMR90 & 260 & 0.113 & 2.38 & 360 & 205 & 79.2 & 289 & 51 & 19.7 & 70.9 \\
\hline & TMR100 & 264 & 0.122 & 2.52 & 363 & 206 & 78.1 & 292 & 51.7 & 19.6 & 71.2 \\
\hline SEM & & 4.3 & 0.0025 & 0.118 & 11.5 & 3.80 & 0.58 & 9.50 & 1.71 & 0.58 & 2.97 \\
\hline Linear & & 0.009 & $<0.001$ & $<0.001$ & 0.733 & 0.011 & 0.026 & 0.922 & 0.034 & 0.037 & 0.317 \\
\hline Quadratic & & 0.011 & 0.003 & 0.725 & 0.473 & 0.037 & 0.46 & 0.568 & 0.114 & 0.461 & 0.349 \\
\hline \multirow[t]{11}{*}{ Steers } & TMRO & 322 & 0.080 & 0.95 & 421 & 247 & 78.3 & 363 & 67.9 & 21.5 & 58.7 \\
\hline & TMR10 & 341 & 0.091 & 1.55 & 427 & 272 & 80.8 & 358 & 54.3 & 16.1 & 68.9 \\
\hline & TMR20 & 315 & 0.109 & 2.50 & 390 & 259 & 82.8 & 323 & 53.5 & 17.1 & 66.6 \\
\hline & TMR30 & 327 & 0.087 & 1.13 & 417 & 258 & 80.1 & 347 & 53.5 & 16.6 & 69.4 \\
\hline & TMR40 & 335 & 0.089 & 1.55 & 436 & 264 & 80.0 & 362 & 56.1 & 17.0 & 74.2 \\
\hline & TMR50 & 310 & 0.107 & 2.52 & 393 & 256 & 83.2 & 327 & 51.6 & 16.8 & 65.9 \\
\hline & TMR60 & 311 & 0.090 & 1.58 & 403 & 248 & 80.7 & 332 & 54.3 & 17.7 & 71.4 \\
\hline & TMR70 & 331 & 0.093 & 0.89 & 431 & 260 & 79.5 & 346 & 60.6 & 18.5 & 85 \\
\hline & TMR80 & 322 & 0.110 & 2.23 & 410 & 256 & 80.0 & 329 & 61.4 & 19.2 & 81.3 \\
\hline & TMR90 & 315 & 0.098 & 1.84 & 417 & 253 & 81.2 & 338 & 57 & 18.3 & 79 \\
\hline & TMR100 & 314 & 0.099 & 1.91 & 368 & 250 & 80.3 & 296 & 60.4 & 19.4 & 72.7 \\
\hline SEM & & 6.6 & 0.0021 & 0.200 & 12.7 & 5.3 & 0.59 & 10.9 & 2.36 & 0.59 & 3.18 \\
\hline \multicolumn{12}{|l|}{$P$ value } \\
\hline Linear & & 0.381 & $<0.001$ & 0.003 & 0.007 & 0.012 & 0.532 & 0.011 & 0.507 & 0.532 & 0.032 \\
\hline Quadratic & & 0.011 & 0.652 & 0.615 & 0.051 & 0.800 & 0.528 & 0.074 & 0.016 & 0.528 & 0.084 \\
\hline Pooled SEM & & 5.6 & 0.0020 & 0.164 & 12.1 & 4.60 & 0.59 & 10.2 & 2.07 & 0.59 & 3.08 \\
\hline \multicolumn{12}{|l|}{$P$ value } \\
\hline Inoculum & & $<0.001$ & $<0.001$ & $<0.001$ & $<0.001$ & $<0.001$ & $<0.001$ & $<0.001$ & $<0.001$ & $<0.001$ & $<0.001$ \\
\hline \multicolumn{12}{|l|}{ TMR } \\
\hline Linear & & 0.007 & $<0.001$ & $<0.001$ & 0.019 & 0.076 & 0.218 & 0.036 & 0.068 & 0.218 & 0.022 \\
\hline Quadratic & & 0.004 & 0.028 & 0.798 & 0.049 & 0.001 & 0.330 & 0.079 & 0.020 & 0.331 & 0.054 \\
\hline Inoculum $\times$ TMR & & 0.002 & $<0.001$ & $<0.001$ & 0.011 & $<0.001$ & 0.996 & 0.008 & 0.623 & 0.995 & 0.541 \\
\hline
\end{tabular}

${ }^{\mathrm{a}}$ Moringa oleifera replaced 0 (TMR0), 10 (TMR10), 20 (TMR20), 30 (TMR30), 40 (TMR40), 50 (TMR50), 60 (TMR60), 70 (TMR70), 80 (TMR80), 90 (TMR90), and 100 (TMR100) $\mathrm{g} / 100 \mathrm{~g}$ of soybean meal.

${ }^{b} b$ is the asymptotic gas production ( $\left.\mathrm{mL} / \mathrm{g} \mathrm{DM}\right) ; \mathrm{c}$ is the rate of gas production $(/ \mathrm{h})$; Lag is the initial delay before gas production begins (h).

incubation.

The partitioning factor at $24 \mathrm{~h}$ incubation $\left(\mathrm{PF}_{24}\right.$, a measure of fermentation efficiency) was calculated according to Blümmel et al. (1997). Gas yield $\left(\mathrm{GY}_{24}\right)$ was calculated as the volume of gas ( $\mathrm{mL}$ gas/g DM) produced after $24 \mathrm{~h}$ of incubation divided by the amount of DMD (g).

Short chain fatty acid concentrations (SCFA) were calculated according to Getachew et al. (2002) as:

SCFA $(\mathrm{mmol} / 200 \mathrm{mg} \mathrm{DM})=0.0222 \mathrm{GP}-0.00425$

where: GP is the 24 h net GP ( $\mathrm{mL} / 200 \mathrm{mg} \mathrm{DM})$.

Microbial biomass production (MCP) was calculated (Blümmel et al., 1997) as:

$$
\begin{aligned}
\mathrm{MCP}(\mathrm{mg} / \mathrm{g} \mathrm{DM})= & \text { milligrams DMD } \\
& -(\text { milliliter gas } \times 2.2 \mathrm{mg} / \mathrm{mL})
\end{aligned}
$$

Data of each of the three runs within the same sample of each of the three individual samples of rations were averaged prior to statistical analysis and the mean values of each individual sample were used as the experimental unit. The experimental design was a factorial arrangement with 3 replicates in a randomized complete block design. Data were analyzed using the GLM procedure (SAS, 2002) with the model: $Y_{i j k}=\mu+R_{i}+M_{j}+(R \times M)_{i j}+\varepsilon_{i j k}$ where: $Y_{i j k}$ is the observation, $\mu$ is the population mean, $R_{i}$ is the inoculum source effect, $M_{j}$ is the level of MLM in the ration, $(\mathrm{R} \times \mathrm{M})_{\mathrm{ij}}$ is the interaction between MLM level and inoculum type, and $\varepsilon_{\mathrm{ijk}}$ is the residual error. Tukey test (pdiff adjust = tukey; SAS) was used to compare means. Statistical significance was declared at $\mathrm{P}<0.05$.

\section{Results}

\subsection{Chemical composition}

Replacing soybean meal with MLM gradually decreased DM, $\mathrm{OM}, \mathrm{CP}, \mathrm{NSC}$, and hemicellulose, while it gradually increased EE, $\mathrm{NDF}, \mathrm{ADF}$, and cellulose contents of the rations (Table 1).

\subsection{Biogases production}

Inoculum type $\times$ TMR interactions were observed $(P<0.05)$ for GP parameters and $\mathrm{CH}_{4}$ production (Table 2). Gas production parameters, and $\mathrm{CH}_{4}$ and $\mathrm{CO}_{2}$ productions differed $(P<0.001)$ between goat and steer rumen liquors. Moreover, replacing soybean 

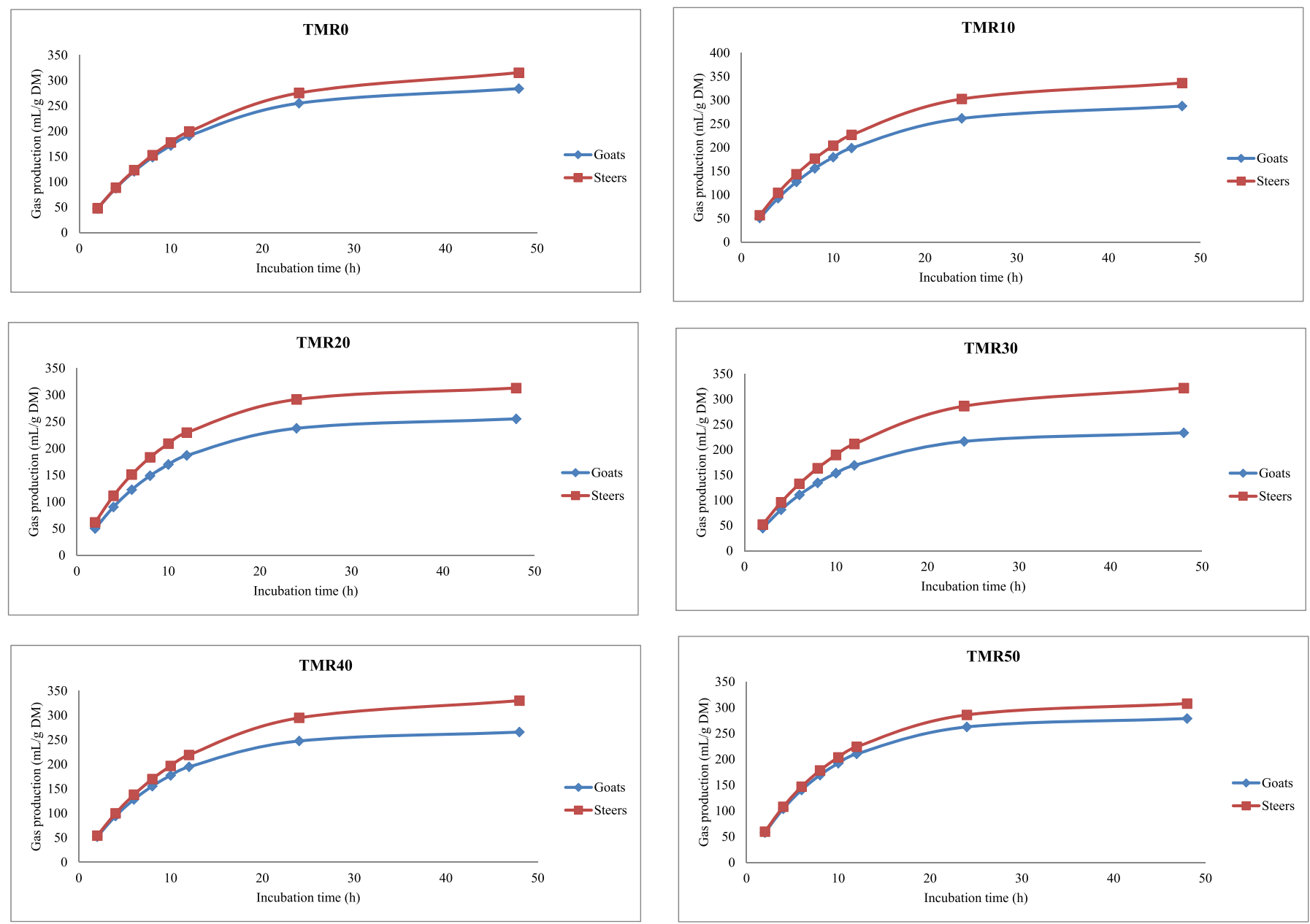

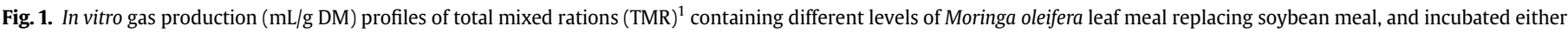

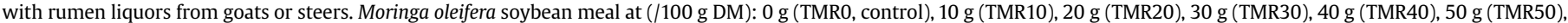
$60 \mathrm{~g}$ (TMR60), $70 \mathrm{~g}$ (TMR70), $80 \mathrm{~g}$ (TMR80), $90 \mathrm{~g}$ (TMR90), and $100 \mathrm{~g}$ (TMR100).

meal with MLM affected GP parameters and $\mathrm{CH}_{4}$ production.

With goat rumen inoculum, replacing soybean meal with MLM decreased the asymptotic GP (linear and quadratic effects; $P<0.01$ ), but increased the rate of GP (linear and quadratic effects; $P<0.01$ ) and lag of GP (linear effect; $P<0.001$ ). On the other hand, excluding TMR10 and TMR40 treatments, MLM-containing rations quadratically decreased $(P=0.011)$ the asymptotic GP, and linearly increased $(P \leq 0.003)$ the rate of GP and the lag time of GP (Fig. 1$)$. However, a very strong relationship $\left(r^{2}=0.99\right)$ between gas production of the total mixed rations containing Moringa oleifera leaf meal replacing soybean meal using goats and steers was observed (Fig. 2).

With rumen inoculum from goats, the inclusion of MLM decreased (linear and quadratic effects, $P<0.05) \mathrm{CH}_{4}$ production and the proportions of $\mathrm{CH}_{4}$ production (linear effect, $P<0.05$ ), while it increased (linear effect, $P<0.05) \mathrm{CO}_{2}$ production (Table 2). With steer inoculum, rations containing MLM quadratically decreased $(P=0.016) \mathrm{CH}_{4}$ production without affecting its proportion, but linearly increased $(P=0.012) \mathrm{CO}_{2}$ production $(\mathrm{ml} / \mathrm{g}$ degraded DM).

\subsection{Fermentation characteristics}

Inoculum $\times$ TMR interactions were observed $(P<0.05)$ for SCFA,
$\mathrm{NH}_{3}-\mathrm{N}, \mathrm{OMD}, \mathrm{ME}, \mathrm{PF} 24, \mathrm{GY} 24$ and MCP (Table 3). All fermentation parameters differed between steers and goats. The ration effect on these parameters was quadratic $(P<0.01)$.

With the goats' rumen liquor, MLM increased fermentation $\mathrm{pH}$ (6.42-6.46, linear effect, $P=0.037)$ and total ruminal bacteria $\left(9.5 \times 10^{5}\right.$ to $13.5 \times 10^{5}$, quadratic effect, $\left.P=0.045\right)$, but decreased ruminal $\mathrm{NH}_{3}-\mathrm{N}$ (linear and quadratic effects, $P<0.05$ ), OMD (quadratic effect, $P=0.033)$, and total protozoa number $\left(5.12 \times 10^{5}\right.$ to $\left.2.88 \times 10^{5}, P=0.015\right)$. The use of steer inoculum decreased SCFA concentrations (quadratic effect, $P=0.005$ ), $\mathrm{NH}_{3}-\mathrm{N}$ (linear and quadratic effects, $P<0.001)$, and total protozoa number $\left(5.77 \times 10^{5}\right.$ to $1.95 \times 10^{5}$, quadratic effect, $P=0.027$ ) were observed when soybean meal was replaced with MLM. However, MLM containing rations increased DMD (linear effect, $P=0.002$ ), OMD (quadratic effect, $P=0.002$ ), ME (quadratic effect, $P=0.002$ ), MCP (quadratic effect, $P=0.005$ ), and total number of bacteria (linear effect, $P=0.021$ ).

\section{Discussion}

\subsection{Chemical composition}

The observed changes in the chemical composition when MLM replaced soybean meal were expected. MLM contains a high fiber 

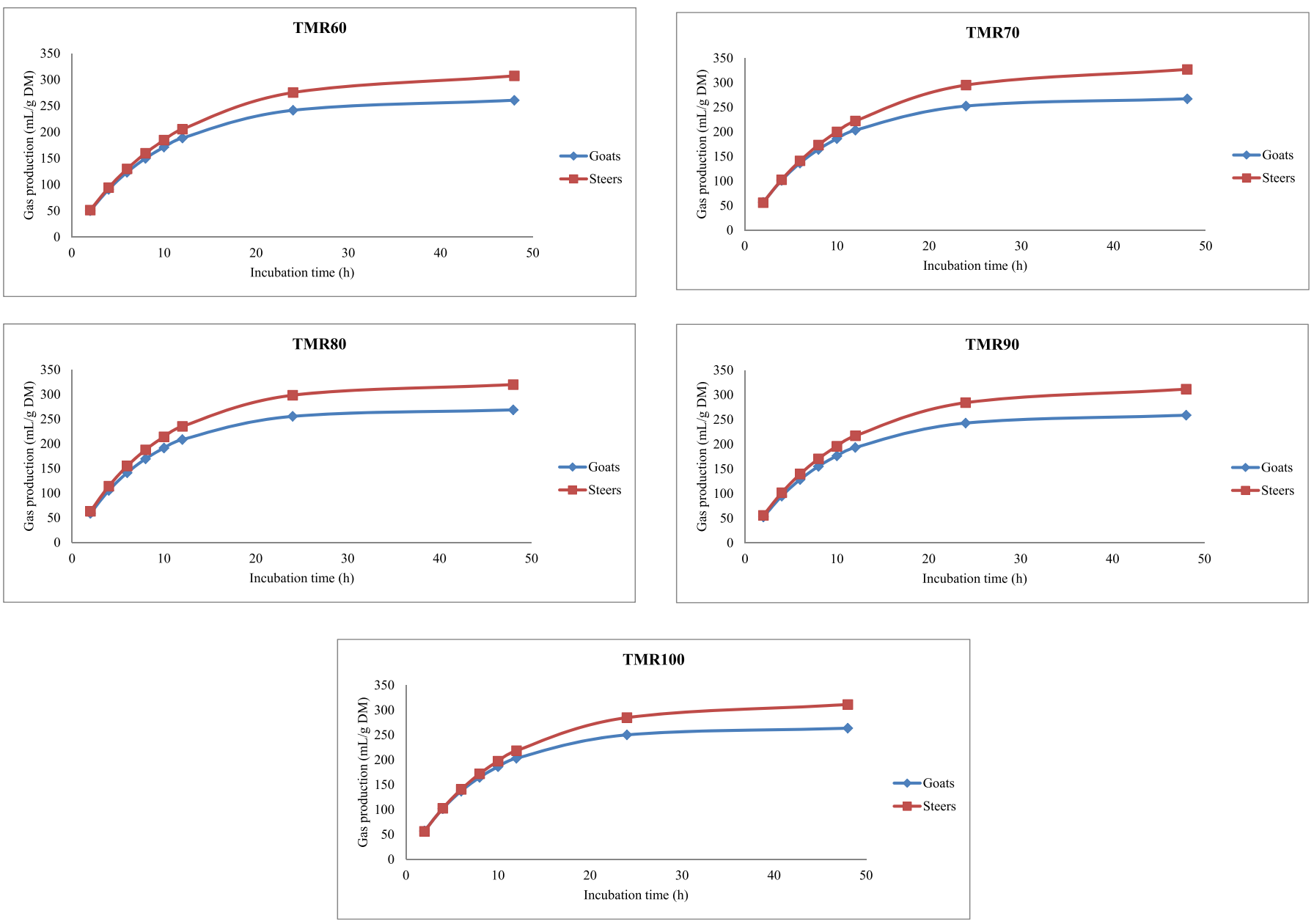

Fig. 1. (continued).

fractions and less crude protein compared with soybean meal. In the present experiment, MLM contained $281 \mathrm{~g}$ CP which represents about $69 \%$ of that contained in the soybean meal ( $408 \mathrm{~g} \mathrm{CP} / \mathrm{kg} \mathrm{MS}$ ). On the other hand, MLM contained about $345 \mathrm{~g}$ NDF versus $143 \mathrm{~g}$ for soybean meal. The chemical composition was expected to affect the fermentation pattern of each ration, as explained later. The protein content of MLM is comparable to sesame meal (26\%), however, less than soybean meal (approximately $40-44 \% \mathrm{CP}$ ), cottonseed meal (approximately $40 \% \mathrm{CP}$ ) and sunflower seed cake (approximately $35 \% \mathrm{CP}$ ), which are the most common sources of protein in ruminant nutrition. Kholif et al. (2015) replaced sesame meal in goat diets with fresh MLM at $0,50,75$, and $100 \%$, and found that the CP content of diets did not change significantly; however, the NDF content of these diets increased. This is a result of almost equally CP content and high NDF content of MLM relative to sesame meal.

\subsection{Gas production}

The observed interactions between the type of inoculum and MLM level for most measured parameters of total gas production (GP) and fermentation reveal that the response to replacing soybean meal with MLM differed between the inoculum provided by goats and steers. These differences may be supported by the significant different response between steers and goat inoculums, and possibly explain differences in the ruminal microbial population and the digesting capacity of the two ruminant species (Fig. 2). This is an important indicator of the importance of using rumen fluid from different ruminant species to inoculate substrates in vitro for incubation cultures, in order to evaluate feed nutritive value. Aderinboye et al. (2016) reported different fermentation parameters with inoculums from cows, sheep and goats. Higher asymptotic GP of steer inoculum suggests that the inoculum supported maximum GP than goat inoculum. It appears that goat inoculum supported greater fermentation but delayed attachment and adaptation of ruminal microbes to the diets than the steer inoculum, based on its higher gas production rate and lag time.

Replacing soybean meal with MLM negatively affected asymptotic GP, lag time of GP and cumulative GP, but positively affected rate of GP. Soliva et al. (2005) observed that complete replacing of soybean meal and rapeseed meal with MLM decreased in vitro total GP. The decreased GP with increasing lag time of GP of MLM diets relative to the control soybean meal diet. This is a direct result of increased fiber concentration in the MLM-containing rations, which might have affected fermentability and also possibly delayed microbial attachment and adaptation. Kholif et al. (2017b) stated that increased fiber portion in TMR decreased asymptotic and cumulative GP but increased rate and lag time of GP. In another experiment where a relatively more fibrous and lower protein ingredient (corn silage) was used to replace a less fibrous and higher protein feed (concentrate mixture) in different maize silage: concentrate ratio diets, Elghandour et al. (2015) observed decreased GP and increased the lag time with increasing corn silage ratio in the TMR. Moreover, the reduced CP concentration in MLM 
rations can also partially explain the decreased GP, in consonance with previous observations (Elghandour et al., 2017) where increased CP content of a ration enhances GP. It was expected that the observed increased bacterial number with MLM would increase GP, but this did not occur. The reasons for these observations are unknown.

The presence of plant secondary metabolites in MLM can be another reason for the negatively affected ruminal fermentation. Generally, the secondary metabolites at high doses have a great antimicrobial activity against ruminal bacteria, protozoa and fungi (Bodas et al., 2012). The antimicrobial effect depends on plant species, the chemical composition of plants, and the dose fed to animal (Bodas et al., 2012). Therefore, the secondary metabolites sometimes can stimulate rumen microbial activity (Benchaar et al., 2008), and this may explain the greater GP and shorter lag time in the case of TMR10 and TMR40 rations for steers inoculum. Ruminal microflora can tolerate and degrade low and moderate concentrations of secondary metabolites such as phenolic compounds (Varel et al., 1991) and tannins (Frutos et al., 2004), and utilize them as energy sources. Inoculum $\times$ TMR interactions for asymptotic and cumulative GP, and rate and lag time of GP indicate the importance of choosing the inoculum for incubating ration in which soybean meal is replaced with MLM. For maximum asymptotic and cumulative GP, and shorter lag time, incubation of TMR10 (10\% replacement of soybean meal with MLM) and TMRO (soybean meal as a sole protein source), respectively, the steer inoculum should be encouraged. However, incubation of TMR80 with goat inoculum is required to improve rate of GP.

Many reports have shown that goats have a higher ability to tolerate high levels of tannins compared with other ruminant species (Frutos et al., 2004; Yisehak et al., 2016). In the present experiment, ruminal microflora from steers showed better response compared with that of goats, which is not in line with Frutos et al. (2004) and Yisehak et al. (2016). This may be due to the previous feed fed to the goats and steers before starting the experiment. Ruminal microbial population depends mainly on the type of diet fed; therefore, based on the fact that both steers and goats in the present experiment were maintained on the same diet, microbial species were not expected to vary (Mould et al., 2005).

\subsection{Biogases production}

Reducing $\mathrm{CH}_{4}$ production from livestock is always desirable from the environmental point of view. The decreased $\mathrm{CH}_{4}$ production with MLM-containing rations may be related to the secondary metabolites such as tannins and saponins present in MLM, or the high proportion of $\alpha$-linolenic acid (Machmüller et al., 2000) in MLM (Soliva et al., 2005). A decreased $\mathrm{CH}_{4}$ production was observed by Soliva et al. (2005) using MLM diets compared with soybean meal diets. The antimicrobial and protozoal effects of secondary metabolites such as tannins can be a direct reason for the decline in $\mathrm{CH}_{4}$ production (Bodas et al., 2012). Moreover, the adverse effect of secondary metabolites on cellulolytic bacteria (Patra and Saxena, 2009) can cause a reduction in $\mathrm{CO}_{2}$ and $\mathrm{H}_{2}$ formation, which are required for methanogenesis, as a result of decreased SCFA production, in particular acetate (Goel and Makkar, 2012), causing a reduction in $\mathrm{CH}_{4}$ production. Moreover, Jayanegara et al. (2011) reported mitigating effects of phenolic compounds on $\mathrm{CH}_{4}$ production. Goel and Makkar (2012) reported up to 50\% reduction of $\mathrm{CH}_{4}$ production in response to tannins and phenolic compounds. In the current study, $\mathrm{CH}_{4}$ production was reduced by $8 \%$ and $10 \%$ in goats and steers, respectively, fed MLM diets compared to the soybean control diet. Greater gas and $\mathrm{CH}_{4}$ productions from cattle inoculum indicates cattle contribute more to biogas emission than goats. Inoculum $\times$ TMR interaction for $\mathrm{CH}_{4}$ production showed that $\mathrm{CH}_{4}$ emission can be abated when soybean bean was completely replaced with MLM (TMR100) using goat inoculum.

\subsection{Ruminal microflora}

Increased ruminal bacterial number with MLM diets in both goat and steer was not expected based on the antimicrobial properties of secondary metabolites in MLM (Bodas et al., 2012). However, the reports of Varel et al. (1991) and Frutos et al. (2004) on the ability of ruminal microflora to degrade and utilize secondary metabolites as energy sources can explain the increased ruminal bacterial number. The increased bacterial populations seem to be a consequence of the observed inhibition of ruminal protozoa in both ruminant species (Newbold et al., 1997; Goel et al., 2008), as ruminal protozoa is the main predators of bacteria in the rumen (Mathieu et al., 1996). Ruminal bacteria population was greatest for TMR30 in goat and TMR100 in steer, while protozoa population was lowest for TMR100 and TMR20 in goat and steer, respectively. Higher bacterial and protozoa population in goat inoculum than in steer inoculum confirms the assertion that goats have a higher threshold for taninniferous diets compared to other ruminant species.

However, the increased bacterial number with MLM rations did not result in a greater GP, ruminal DM degradability and SCFA production of goats. This may be due to the fact that not all bacteria species are affected in the same way. For example, tannins and saponins are particularly able to inhibit Gram-positive bacteria more than Gram negative bacteria (Bodas et al., 2012). Thus, the increased bacterial number might be due to increase in other species and not cellulolytic bacteria.

The decreased protozoal number when soybean meal was
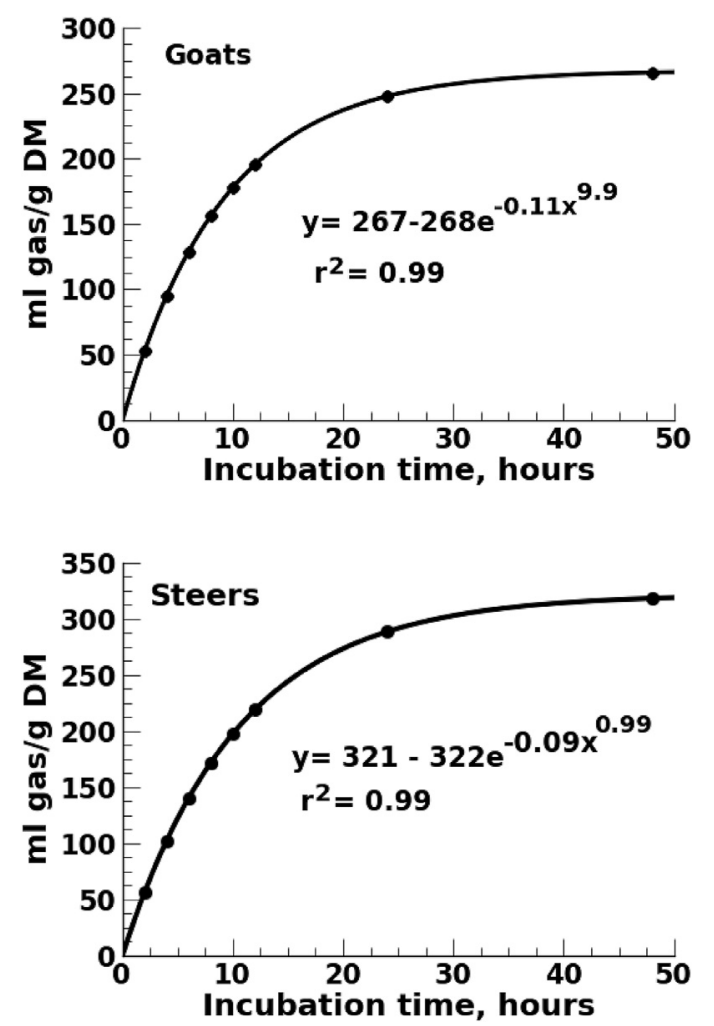

Fig. 2. Relationship $\left(\mathrm{r}^{2}\right)$ between in vitro gas production using goats and steers of total mixed rations (TMR) ${ }^{1}$ containing different levels of Moringa oleifera leaf meal replacing soybean meal. 
Table 3

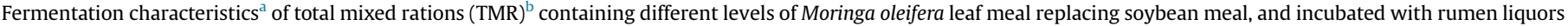
obtained from goats or steers.

\begin{tabular}{|c|c|c|c|c|c|c|c|c|c|c|c|c|}
\hline Inoculum & TMR & $\mathrm{pH}$ & SCFA & $\mathrm{NH}_{3}-\mathrm{N}$ & DMD & OMD & $\mathrm{ME}$ & $\mathrm{PF}_{24}$ & $\mathrm{GY}_{24}$ & $\mathrm{MCP}$ & Total bacteria $\times 10^{8}$ & Total protozoa $\times 10^{5}$ \\
\hline \multirow[t]{11}{*}{ Goat } & TMRO & 6.42 & 5.65 & 69.6 & 771 & 702 & 10.3 & 5.15 & 194 & 753 & 9.50 & 5.12 \\
\hline & TMR10 & 6.44 & 5.78 & 65.3 & 765 & 712 & 10.5 & 5.13 & 195 & 765 & 10.3 & 4.27 \\
\hline & TMR20 & 6.47 & 5.25 & 58.6 & 763 & 665 & 9.80 & 5.23 & 191 & 720 & 13.1 & 3.42 \\
\hline & TMR30 & 6.45 & 4.78 & 58.8 & 756 & 629 & 9.20 & 5.35 & 187 & 681 & 13.5 & 3.96 \\
\hline & TMR40 & 6.44 & 5.48 & 60.2 & 745 & 679 & 10.0 & 5.18 & 193 & 739 & 11.3 & 3.27 \\
\hline & TMR50 & 6.46 & 5.81 & 58.4 & 734 & 708 & 10.5 & 5.12 & 195 & 767 & 11.1 & 3.44 \\
\hline & TMR60 & 6.48 & 5.34 & 53.9 & 759 & 668 & 9.9 & 5.21 & 192 & 728 & 11.4 & 3.62 \\
\hline & TMR70 & 6.44 & 5.59 & 56.6 & 734 & 685 & 10.1 & 5.16 & 194 & 748 & 13.2 & 4.10 \\
\hline & TMR80 & 6.46 & 5.65 & 49.0 & 755 & 689 & 10.2 & 5.15 & 194 & 754 & 11.0 & 3.93 \\
\hline & TMR90 & 6.40 & 5.37 & 51.0 & 720 & 667 & 9.80 & 5.21 & 192 & 730 & 11.3 & 3.92 \\
\hline & TMR100 & 6.44 & 5.53 & 52.0 & 727 & 681 & 10.0 & 5.18 & 193 & 744 & 11.4 & 2.88 \\
\hline SEM & & 0.005 & 0.093 & 1.37 & 15.7 & 7.50 & 0.11 & 0.018 & 0.70 & 7.80 & 0.810 & 0.203 \\
\hline Linear & & 0.037 & 0.399 & $<0.001$ & 0.062 & 0.059 & 0.074 & 0.308 & 0.412 & 0.403 & 0.733 & 0.812 \\
\hline Quadratic & & 0.087 & 0.104 & 0.014 & 0.399 & 0.033 & 0.338 & 0.111 & 0.105 & 0.100 & 0.045 & 0.015 \\
\hline \multirow[t]{11}{*}{ Steers } & TMRO & 6.40 & 6.09 & 65.9 & 750 & 738 & 10.9 & 5.07 & 197 & 791 & 9.38 & 5.77 \\
\hline & TMR10 & 6.43 & 6.70 & 63.4 & 789 & 785 & 11.6 & 4.98 & 201 & 842 & 10.53 & 3.21 \\
\hline & TMR20 & 6.44 & 6.45 & 61.0 & 803 & 761 & 11.3 & 5.01 & 199 & 821 & 10.63 & 1.95 \\
\hline & TMR30 & 6.40 & 6.33 & 56.9 & 774 & 752 & 11.1 & 5.04 & 199 & 811 & 11.55 & 3.60 \\
\hline & TMR40 & 6.44 & 6.53 & 61.2 & 758 & 763 & 11.3 & 5.01 & 200 & 827 & 12.12 & 3.70 \\
\hline & TMR50 & 6.46 & 6.33 & 53.2 & 783 & 750 & 11.1 & 5.04 & 199 & 811 & 9.98 & 3.07 \\
\hline & TMR60 & 6.39 & 6.09 & 57.6 & 763 & 728 & 10.8 & 5.07 & 197 & 791 & 10.25 & 3.38 \\
\hline & TMR70 & 6.42 & 6.53 & 61.1 & 761 & 760 & 11.3 & 5.00 & 200 & 828 & 10.00 & 2.77 \\
\hline & TMR80 & 6.40 & 6.60 & 61.4 & 782 & 765 & 11.3 & 5.00 & 200 & 834 & 12.40 & 3.74 \\
\hline & TMR90 & 6.38 & 6.29 & 53.9 & 748 & 740 & 11.0 & 5.04 & 198 & 807 & 12.07 & 3.39 \\
\hline & TMR100 & 6.41 & 6.30 & 56.3 & 846 & 742 & 11.0 & 5.04 & 198 & 809 & 13.22 & 4.62 \\
\hline SEM & & 0.010 & 0.130 & 1.92 & 19.1 & 10.4 & 0.16 & 0.019 & 0.70 & 10.9 & 0.31 & 1.11 \\
\hline Linear & & 0.351 & 0.258 & $<0.001$ & 0.002 & 0.771 & 0.673 & 0.190 & 0.229 & 0.263 & 0.021 & 0.410 \\
\hline Quadratic & & 0.067 & 0.005 & $<0.001$ & 0.704 & 0.002 & 0.002 & 0.600 & 0.441 & 0.005 & 0.769 & 0.027 \\
\hline $\begin{array}{l}\text { Pooled SEM } \\
P \text { value }\end{array}$ & & 0.008 & 0.113 & 1.67 & 17.5 & 9.10 & 0.14 & 0.019 & 0.70 & 9.50 & 1.963 & 0.710 \\
\hline Inoculum & & $<0.001$ & $<0.001$ & 0.0009 & 0.0003 & $<0.001$ & $<0.001$ & $<0.001$ & $<0.001$ & $<0.001$ & 0.748 & 0.606 \\
\hline \multicolumn{13}{|l|}{ TMR } \\
\hline Linear & & 0.066 & 0.660 & $<0.001$ & 0.146 & 0.363 & 0.466 & 0.790 & 0.726 & 0.664 & 0.023 & 0.047 \\
\hline Quadratic & & 0.015 & 0.001 & $<0.001$ & 0.805 & 0.001 & 0.001 & 0.002 & 0.001 & 0.009 & 0.477 & 0.818 \\
\hline Inoculum $\times$ TMR & & 0.700 & 0.001 & $<0.001$ & 0.059 & 0.002 & 0.001 & $<0.001$ & $<0.001$ & 0.001 & 0.941 & 0.518 \\
\hline
\end{tabular}

a DMD is dry matter degradability (mg/g DM), GY 24 is gas yield at $24 \mathrm{~h}$ (mL gas/g DMD), MCP is microbial protein production (mg/g DM), ME is metabolizable energy (MJ/kg

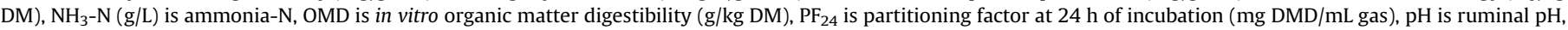
SCFA is short-chain fatty acids ( $\mathrm{mmol} / \mathrm{g} \mathrm{DM})$.

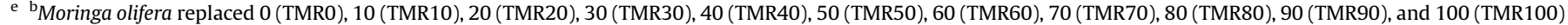
$\mathrm{g} / 100 \mathrm{~g}$ of soybean meal.

replaced with MLM is a result of the marked anti-protozoal activity of secondary metabolites such as saponins, tannins and phenolic compounds (Makkar et al., 1995; Bodas et al., 2012). Bhatta et al. (2009) reported that tannins have a clear defaunating effect, without a clear mode of action. Decreasing ruminal protozoa population is desirable because this will result in lower $\mathrm{CH}_{4}$ production and higher bacterial numbers.

\subsection{Fermentation profile}

Increasing ruminal $\mathrm{pH}$ in goat nutrition is desirable for better ruminal condition for cellulolytic bacteria activity. Ruminal $\mathrm{pH}$ values ranged between 6.42 and 6.48 , and fell within the range considered acceptable for fiber digestion (Ørskov and Ryle, 1990). Greatest ruminal pH was observed in TMR60 for goats. Generally, ruminal $\mathrm{pH}$ was higher in MLM diets than the control diet possibly due to higher fiber content of MLM (Olafadehan and Adebayo, 2016).

Ruminal $\mathrm{NH}_{3}-\mathrm{N}$ concentrations, in the present experiment, ranged from 49.0 to $69.6 \mathrm{~g} / \mathrm{L}$, and were above the range required for sufficient microbial protein synthesis (Satter and Slyter, 1974). The decreased ruminal $\mathrm{NH}_{3}-\mathrm{N}$ with MLM is a result of the reported low degradability of MLM protein in the rumen (Kholif et al., 2015) due to its tannins and phenolic compounds (Bodas et al., 2012). Tannins in feeds may reduce ruminal protein degradation because tannins bind to dietary protein and protect it from ruminal degradation (Frutos et al., 2004). Besides, secondary metabolites such as saponins and tannins have the ability to decrease ruminal protozoa (Newbold et al., 1997), as we previously showed. Protozoa play a major role in ruminal feed protein degradation (Jouany, 1996). Another probable reason for the decreased $\mathrm{NH}_{3}-\mathrm{N}$ is the inhibition of hyper $\mathrm{NH}_{3}$-producing bacteria activity and their deaminase activity (Newbold et al., 2004).

The increased bacterial numbers with the MLM-containing diets did not result in increased OMD or SCFA production when goat inoculum was used. The negatively affected nutrient degradability in MLM-containing rations may be due to the negative effects of increasing fiber concentration and the declining CP concentration on ruminal fermentation. Frutos et al. (2004) reported that less than $50 \mathrm{mg} / \mathrm{g}$ DM is the acceptable level of tannins in feeds without negative effects on digestibility. In the present experiment, tannins concentration was $22 \mathrm{mg} / \mathrm{g}$ DM, which is far below the critical level that suppresses ruminal fermentation. Therefore, tannins cannot be the main reason for the decreased degradation, but the increasing fiber concentration in MLM rations could have decreased degradation, as speculated earlier. Elghandour et al. (2015) observed that increasing fiber concentration in a ration reduced nutrient degradability. In steer nutrition, the result of DMD was contrary to the observed result in goat nutrition. Differences in ruminal microflora response to secondary metabolites might be the reason. 
Decreased SCFA concentration can be interpreted as a result of declined degradability of MLM-containing ration. Olafadehan and Okunade (2016) attributed decreased ruminal SCFA concentration to reduced digesta degradability in the rumen. Results of decreasing $\mathrm{NH}_{3}-\mathrm{N}$ and total SCFA concentrations are an evidence of improved synchronization between dietary energy and protein, which is expected to increase microbial-N production within the rumen (Seo et al., 2013). Soliva et al. (2005) compared the ruminal fermentation of MLM with soybean meal and rapeseed meal, and observed unaffected ruminal pH values and SCFA concentration, and a decreased ruminal $\mathrm{NH}_{3}-\mathrm{N}$ concentration with MLM. Higher SCFA, $\mathrm{NH}_{3}-\mathrm{N}, \mathrm{DMD}, \mathrm{OMD} \mathrm{ME}$ and MCP in cattle inoculum suggests that the inoculum enhanced ruminal fermentation relative to goat inoculum.

From the present results, future studies in which $\mathrm{CH}_{4}$ emission abatement due to replacement of soybean meal with MLM in in vivo trials, using the three major ruminant species (cattle, sheep and goats), to validate our current results should be conducted.

\section{Conclusion}

From the nutritional perspective, $M$. oleifera cannot replace soybean meal as a protein source in diets for goats and steers because of the negative effect on ruminal fermentation. However, from an environmental point of view, replacing soybean meal with M. oleifera leaf meal reduced $\mathrm{CH}_{4}$ production, which can be used as a good "cleaner" product for the environment and feedstuff for ruminants to mitigate the environmental contamination by biogases pollution emanated from these animals. More research will be desirable to determine the best levels of replacement on feed utilization and methane production in dairy and beef cattle, wool and meat sheep and dairy goats. Besides, more experiment should be carried out to replace other protein feeds with low protein concentrates such as sesame meal and rapeseed meal with $M$. oleifera at different levels in both in vitro and in vivo trials.

\section{Conflict of interest}

All authors declare that there are no present or potential conflicts of interest between them and other people or organizations that could inappropriately bias their work.

\section{Acknowledgements}

Authors would like to appreciate the financial support from Universidad Autónoma del Estado de México (Project UAEM 4304/ $2017 / C I$ ). Authors also appreciate the great efforts of A.E. Kholif by his valuable comments and recommendations.

\section{References}

Aderinboye, R.Y., Akinlolu, A.O., Adeleke, M.A., Najeem, G.O., Ojo, V.O.A., Isah, O.A. Babayemi, O.J., 2016. In vitro gas production and dry matter degradation of four browse leaves using cattle, sheep and goat inocula. Slovak J. Anim. Sci. 49, $32-43$.

AOAC, 1997. Official Methods of Analysis, sixteenth ed. Association of Official Analytical Chemists, Washington, DC., USA.

Becker, K., 1995. Studies on Utilization of Moringa Oleifera Leaves as Animal Feed. In: Institute for Animal Production in the Tropics and Subtropics, vol. 480. University of Hohenheim, Stuttgart, p. 15.

Benchaar, C., Calsamiglia, S., Chaves, A.V., Fraser, G.R., Colombatto, D. McAllister, T.A., Beauchemin, K.A., 2008. A review of plant-derived essential oils in ruminant nutrition and production. Anim. Feed Sci. Technol. 145, 209-228.

Blümmel, M., Steingss, H., Becker, K., 1997. The relationship between in vitro gas production, in vitro microbial biomass yield and ${ }^{15} \mathrm{~N}$ incorporation and its implications for the prediction of voluntary feed intake of roughages. Br. J. Nutr. 77, 911-921.

Bodas, R., Prieto, N., García-González, R., Andrés, S., Giráldez, F.J., López, S., 2012. Manipulation of rumen fermentation and methane production with plant secondary metabolites. Anim. Feed Sci. Technol. 176, 78-93.

Broderick, G.A., Kang, J.H., 1980. Automated simultaneous determination of ammonia and total amino acids in ruminal fluid and in vitro media. J. Dairy Sci. $63,64$.

Calabrò, S., Guglielmelli, A., Iannaccone, F., Danieli, P.P., Tudisco, R., Ruggiero, C., Piccolo, G., Cutrignelli, M.I., Infascelli, F., 2011. Fermentation kinetics of Sainfoin hay with and without PEG. J. Anim. Physiol. Animal Nutr. 96, 842-849.

Elghandour, M.M.Y., Kholif, A.E., Marquez-Molina, O., Vazquez-Armijo, J.F., Puniya, A.K., Salem, A.Z.M., 2015. Influence of individual or mixed cellulase and xylanase mixture on in vitro rumen gas production kinetics of total mixed rations with different maize silage and concentrate ratios. Turk. J. Vet. Anim. Sci. 39 (4), 435-442.

Elghandour, M.M.Y., Kholif, A.E. Salem, A.Z.M. de Oca, R.M. Barbabosa, A. Mariezcurrena, M., Olafadehan, O.A., 2016. Addressing sustainable ruminal methane and carbon dioxide emissions of soybean hulls by organic acid salts. J. Clean. Prod. 135, 194-200.

Elghandour, M.M.Y., Vázquez, J.C., Salem, A.Z.M., Kholif, A.E., Cipriano, M.M., Camacho, L.M., Márquez, O., 2017. In vitro gas and methane production of two mixed rations influenced by three different cultures of Saccharomyces cerevisiae. J. Appl. Anim. Res. 45, 389-395.

FAO (Food and Agriculture Organization of the United Nations), 2006. Livestock a Major Threat to the Environment: Remedies Urgently Needed. Available: http:// www.fao.org/newsroom/en/news/2006/1000448/index.html. (Accessed 15 August 2016)

Fedorak, P.M., Hrudey, S.E., 1983. A simple apparatus for measuring gas-production by methanogenic cultures in serum bottles. Environ. Technol. Lett. 4, 425-432.

France, J., Dijkstra, J., Dhanoa, M.S., Lopez, S., Bannink, A., 2000. Estimating theextent of degradation of ruminant feeds from a description of their gas production profiles observed in vitro: derivation of models and other mathematical considerations. Br. J. Nutr. 83, 143-150.

Frutos, P., Hervás, G., Giráldez, F.J., Mantecón, A.R., 2004. Review. Tannins and ruminant nutrition. Span. J. Agric. Res. 2, 191-202.

Getachew, G., Makkar, H.P.S., Becker, K., 2002. Tropical browses: contents of phenolic compounds, in vitro gas production and stoichiometric relationship between short chain fatty acid and in vitro gas production. J. Agr. Sci. Camb. 139, $341-352$.

Goel, G., Makkar, H.P.S., 2012. Methane mitigation from ruminants using tannins and saponins. Trop. Anim. Health Prod. 4, 729-739.

Goel, G., Makkar, H.P.S., Becker, K., 2008. Changes in microbial community structure, methanogenesis and rumen fermentation in response to saponin-rich fractions from different plant materials. J. Appl. Microbiol. 105, 770-777.

Goering, M.K., Van Soest, P.J., 1970. Forage Fiber Analysis (Apparatus, Reagents, Procedures and Some Applications). Agriculture Handbook, No 379. Agricultural Research Service, USDA, Washington, DC.

Gopalakrishnan, L., Doriya, K., Kumar, D.S., 2016. Moringa oleifera: a review on nutritive importance and its medicinal application. Food Sci. Hum. Wellness 5, 49-56.

Guglielmelli, A., Calabrò, S, Primi, R. Carone, F, Cutrignelli, M.L, Tudisco, R., Piccolo, G., Ronchi, B., Danieli, P.P., 2011. In vitro fermentation patterns and methane production of sainfoin (Onobrychis viciifolia Scop.) hay with different condensed tannin contents. Grass Forage Sci. 66, 488-500.

Hernandez, A., Kholif, A.E., Lugo-Coyote, R., Elghandour, M.M.Y., Cipriano, M., Rodríguez, G.B., Odongo, N.E., Salem, A.Z.M., 2017. The effect of garlic oil, xylanase enzyme and yeast on biomethane and carbon dioxide production from 60-d old Holstein dairy calves fed a high concentrate diet. J. Clean. Prod. 142, 2384-2392.

Jayanegara, A., Wina, E., Soliva, C.R., Marquardt, S., Kreuzer, M., Leiber, F., 2011. Dependence of forage quality and methanogenic potential of tropical plants on their phenolic fractions as determined by principal component analysis. Anim. Feed Sci. Tech. 163, 231-243.

Jouany, J.P., 1996. Effect of rumen protozoa on nitrogen utilization by ruminants: altering ruminal nitrogen metabolism to improve protein utilization. J. Nutr. 126, 1335S-1346S.

Kholif, A.E., Gouda, G.A., Morsy, T.A., Salem, A.Z.M., Lopez, S., Kholif, A.M., 2015. Moringa oleifera leaf meal as a protein source in lactating goat's diets: feed intake, digestibility, ruminal fermentation, milk yield and composition, and its fatty acids profile. Small Rumin. Res. 129, 129-137.

Kholif, A.E., Elghandour, M.M.Y., Rodríguez, G.B., Olafadehan, O.A., Salem, A.Z.M., 2017a. Anaerobic ensiling of raw agricultural waste with a fibrolytic enzyme cocktail as a cleaner and sustainable biological product. J. Clean. Prod. 42, 2649-2655.

Kholif, A.E., Elghandour, M.M.Y., Salem, A.Z.M., Barbabosa, A., Márquez, O. Odongo, N.E., 2017b. The effects of three total mixed rations with different concentrate to maize silage ratios and different levels of microalgae Chlorella vulgaris on in vitro total gas, methane and carbon dioxide production. J. Agric. Sci. 155, 494-507.

Ku-Vera, J.C., Canul-Solis, J.R., Pineiro,-Vazquez, A.T., Briceno-Poot, E.G., AlayonGamboa, J.A., Ayala-Burgos, A.J., Solorio-Sanchez, F.J., Aguilar-Perez, C.F., Ramirez-Aviles, L., Castelan-Ortega, O.A., 2013. Methane emissions from ruminants in the tropics: implications for global warming and options for mitigation. In: Basile, A. (Ed.), Methane in the Environment: Occurrence, Uses and Production. Nova Science Publishers, Inc., NY, pp. 267-290.

Machmüller, A., Ossowski, D.A., Kreuzer, M., 2000. Comparative evaluation of the effects of coconut oil, oilseeds and crystalline fat on methane release, digestion and energy balance in lambs. Anim. Feed Sci. Technol. 85, 41-60. 
Makkar, H.P.S., 2003. Quantification of Tannins in Tree and Shrub Foliage. Kluwer Academic, Dordrecht, p. 102

Makkar, H.P.S., 2016. Smart livestock feeding strategies for harvesting triple gain the desired outcomes in planet, people and profit dimensions: a developing country perspective. Anim. Prod. Sci. 56, 519-534.

Makkar, H.P.S., Blümmel, M., Becker, K., 1995. Formation of complexes between polyvinyl pyrrolidones or polyethylene glycols and tannins and their implications in gas production and true digestibility in in vitro techniques. Br. J. Nutr. 73, 897-933.

Mathieu, F., Jouany, J., Senaud, J., Bohatier, J., Bertin, G., Mercier, M., 1996. The effect of Saccharomyces cerevisiae and Aspergillus oryzae on fermentations in the rumen of faunated and defaunated sheep; protozoal and probiotic interactions. Reprod. Nutr. Dev. 36, 271-287.

Meier, B., Julkunen-Tiitto, R., Tahvanainen, J., Sticher, O., 1988. Comparative highperformance liquid and gas-liquid chromatographic determination of phenolic glucosides in Salicaceae species. J. Chromatogr. 442, 175-186.

Menke, K.H., Raab, L., Salewski, A., Steingass, H., Fritz, D., Schneider, W., 1979. The estimation of the digestibility and metabolizable energy content of ruminant feeding stuffs from the gas production when they are incubated with rumen liquor in vitro. J. Agr. Sci. Camb. 93, 217-222.

Moss, A.R., Jouany, J.P., Newbold, J., 2000. Methane production by ruminants: its contribution to global warming. Ann. Zootech. 49, 231-253.

Mould, F.L., Kliem, K.E., Morgan, R., Mauricio, R.M., 2005. In vitro microbial inoculum: a review of its function and properties. Anim. Feed Sci. Technol. 123, $31-50$.

Newbold, C.J., El Hassan, S.M., Wang, J., Ortega, M., Wallace, R.J., 1997. Influence of foliage from African multipurpose trees on activity of rumen protozoa and bacteria. Br. J. Nutr. 78, 237-249.

Newbold, C.J., McIntosh, F.M., Williams, P., Losa, R., Wallace, R.J., 2004. Effects of a specific blend of essential oil compounds on rumen fermentation. Anim. Feed Sci. Technol. 114, 105-112.

Nouman, W., Anwar, F., Gull, T., Newton, A., Rosa, E., Domínguez-Perles, R., 2016. Profiling of polyphenolics, nutrients and antioxidant potential of germplasm's leaves from seven cultivars of Moringa oleifera Lam. Industr. Crops Prod. 83, $166-176$.

Olafadehan, O.A., Adebayo, O.F., 2016. Nutritional evaluation of ammoniated threshed sorghum top as a feed for growing goats. Trop. Anim. Health Prod. 48 785-791.

Olafadehan, O.A., Okunade, S.A., 2016. Fodder value of three browse forages for growing goats. J. Saudi Soc. Agric. Sci. http://dx.doi.org/10.1016 j.jssas.2016.01.001.

Ørskov, E.R., Ryle, R., 1990. Energy Nutrition in Ruminants. Elsevier Science Publishers, New York.

Patra, A.K., Saxena, J., 2009. Dietary phytochemicals as rumen modifiers: a review of the effects on microbial populations. Anton. Leeuwen 96, 363-375.

Safwat, M.A., Sarmiento-Franco, L., Santos-Ricalde, R.H., 2014. Rabbit production using local resources as feedstuffs in the tropics. Trop. Subtrop. Agroecosyst. 17 $161-171$.

Sánchez-Machado, D., Núñez-Gastélum, J., Reyes-Moreno, C., Ramírez-Wong, B. López-Cervantes, J., 2010. Nutritional quality of edible parts of Moringa oleifera. Food Anal. Method 3, 175-180.

SAS, 2002. Statistical Analysis System. User's Guide: Statistics. Ver 9.0. SAS Institute Cary, NC.

Satter, L.D., Slyter, L.L., 1974. Effect of ammonia concentration on rumen microbial protein production in vitro. Br. J. Nutr. 32, 199-208.

Seo, J.K., Kim, M.H., Yang, J.Y., Kim, H.J., Lee, C.H., Kim, K.H., Ha, J.K., 2013. Effects of synchronicity of carbohydrate and protein degradation on rumen fermentation characteristics and microbial protein synthesis. Asian Australas. J. Anim. Sci. 26 358-365.

Van Soest, P.J., Robertson, J.B., Lewis, B.A., 1991. Methods for dietary fibre, neutral detergent fibre, and non-starch carbohydrates in relation to animal nutrition. J. Dairy Sci. 74, 3583-3597.

Soliva, C.R., Kreuzer, M., Foidl, N., Foidl, G., Machmüller, A., Hess, H.D., 2005. Feeding value of whole and extracted Moringa oleifera leaves for ruminants and their effects on ruminal fermentation in vitro. Anim. Feed Sci. Technol. 118, 47-62.

Varel, V.H., Jung, H.G., Krumholz, L.R., 1991. Degradation of cellulose and forage fibe fractions by ruminal cellulolytic bacteria alone and in coculture with phenolic monomer-degrading bacteria. J. Anim. Sci. 69, 4993-5000.

Yisehak, K., Kibreab, Y., Taye, T., Lourenço, M.R.A., Janssens, G.P.J., 2016. Response to dietary tannin challenges in view of the browser/grazer dichotomy in an Ethiopian setting: bonga sheep versus Kaffa goats. Trop. Anim. Health Prod. 48, 125-131. 